\title{
A CASE REPORT OF DOPA-RESPONSIVE DYSTONIA IN A YOUNG WOMAN
}

Belykh $\mathrm{NA}^{2} \bowtie$, Akhkyamova $\mathrm{MA}^{2}$, Gusev $\mathrm{W}^{1,2,3}$, Lvova $\mathrm{OA}^{2,3}$

${ }^{1}$ Central Clinical Hospital № 23, Yekaterinburg, Russia

${ }^{2}$ Ural State Medical University, Yekaterinburg, Russia

${ }^{3}$ Yeltsin Ural Federal University, Yekaterinburg, Russia

\begin{abstract}
Dopa-responsive dystonia (DRD) is a rare progressive genetically heterogenous disorder with pediatric onset. DRD is 3 times as prevalent in women than in men. This article reports a clinical case of DRD in a young female presenting with paraparesis, foot dystonia (more pronounced in the right foot) and pronounced walking impairment, who was admitted for emergency treatment to a Neurology Unit. Based on the additional tests, which included a levodopa trial and Sanger sequencing, the patient was diagnosed with DRD. Levodopa caused a considerable improvement of the symptoms. The article describes the clinical features of the disease, talks about its differential diagnosis, genetic predisposition and treatment strategy.
\end{abstract}

Keywords: DOPA-responsive dystonia, Segawa syndrome, hereditary dystonia

Author contribution: Belykh NA analyzed the literature, made the differential diagnosis, participated in establishing the definitive diagnoses followed the patient up for 3 years. Akhkyamova MA examined the patient, collected her medical history, participated in establishing the diagnosis, followed the patient up for 3 years, wrote the manuscript. Gusev W followed the patient up; ordered diagnostic tests, prescribed treatment and monitored its course; provided the patient's medical history; helped with the application to the Ethics Committee. Lvova OA advised the patient on the genetic test and interpreted its results.

Compliance with ethical standards: the study was approved by the Ethics Committee of Ural State Medical University (Protocol № 1451/19 dated September 20, 2019). The patient gave informed consent to participate in the study.

$\measuredangle$ Correspondence should be addressed: Nikita A. Belykh Repina, 3, Yekaterinburg, 620014; nikitabelikh@gmail.com

Received: 14.05.2020 Accepted: 28.05.2020 Published online: 04.06.2020

DOI: 10.24075/brsmu.2020.031

\section{КЛИНИЧЕСКИЙ СЛУЧАЙ ДОФА-ЗАВИСИМОЙ ДИСТОНИИ У МОЛОДОЙ ЖЕНЩИНЫ}

\author{
Н. А. Белых $\mathbf{x}^{2}$ М. А. Ахкямова², В. В. Гусев ${ }^{1,2,3}$, О. А. Львова ${ }^{2,3}$ \\ ${ }^{1}$ Центральная городская клиническая больница № 23, Екатеринбург, Россия \\ 2 Уральский государственный медицинский университет, Екатеринбург, Россия \\ ${ }^{3}$ Уральский федеральный университет имени первого Президента России Б. Н. Ельцина, Екатеринбург, Россия
}

\begin{abstract}
ДОФА-зависимая дистония (ДЗД) - это редкое прогрессирующее генетически гетерогенное заболевание с манифестированием в детском возрасте, в три раза чаще встречающееся у женщин. В статье описан клинический случай синдрома Сегавы у молодой женщины с нижним парапарезом, дистонией стоп (больше справа), нарушением функции ходьбы, поступившей в неотложном порядке в неврологическое отделение с жалобами на выраженное ограничение ходьбы и самообслуживания. В результате дообследования, включающего в себя тест с Леводопой и прямое автоматическое секвенирование по Сенгеру, у пациентки была диагностирована ДЗД. Проведено лечение Леводопой, в ходе которого у пациентки регрессировали клинические симптомы дистонии. В статье представлены особенности течения заболевания и дифференциальной диагностики, а также генетическая детерминированность и тактика лечения.
\end{abstract}

Ключевые слова: ДОФА-зависимая дистония, синдром Сегавы, наследственная дистония

Вклад авторов: Н. А. Белых - сбор материала по заболеванию, дифференциальная диагностика, участие в постановке окончательного диагноза, наблюдение пациента в течение трех лет; М. А. Ахкямова - осмотр пациента, сбор анамнеза заболевания, участие в диагностике, наблюдение пациента в течение трех лет, редактирование рукописи; В. В. Гусев — наблюдение пациента в течение трех лет, назначение диагностических методов исследования, подбор и контроль лечения, предоставление истории болезни пациента для написания статьи, организация этического комитета; О. А. Львова - рекомендации по генетическому исследованию, интерпретация результатов, генетическое консультирование.

Соблюдение этических стандартов: исследование одобрено этическим комитетом Уральского государственного медицинского университета (протокол № 1451/19 от 20 сентября 2019 г.). Получено добровольное информированное согласие на участие пациента в научном исследовании.

$凶$ Для корреспонденции: Никита Алексеевич Белых ул. Репина, 3, г. Екатеринбург, 620014; nikitabelikh@gmail.com

Статья получена: 14.05.2020 Статья принята к печати: 28.05.2020 Опубликована онлайн: 04.06.2020

DOI: 10.24075/vrgmu.2020.031

Dopa-responsive dystonia (DRD) is a form of torsion dystonia first described by the Japanese neurologist Segawa in 1971 as progressive hereditary dystonia with prominent diurnal fluctuations [1].

In most patients, the disease starts in one leg in the first decade of life and spreads to other limbs by the time the patient enters their late 20s [2]. Gait disturbance is typically the earliest manifestation of DRD often mistakenly interpreted as cerebral palsy [3]. In the early stages of the disease, the symptoms are absent in the morning but worsen towards evening; such aggravation depends more on the number of waking hours than on physical activity itself. As the disease progresses, the patient starts to experience morning symptoms as well [4].
There are 2 types of dystonia: classic postural dystonia, e.g. postural instability due to increased muscle tone, and phasic dystonia, which is a combination of postural instability and phasic dystonic movements. There are single reports of isolated hand tremor, permanent foot deformities (clubfoot) and dystonia of individual muscles [5].

A trial of levodopa is the main diagnostic test in patients with suspected DRD. A good, sustained response to this drug indicates a high probability of DRD.

The recommended starting dose of levodopa is $1 \mathrm{mg} / \mathrm{kg}$ per day. It should be gradually increased until sustained improvement is achieved or side effects are reported by the patient. The majority of patients improve at $4-5 \mathrm{mg} / \mathrm{kg}$ per day. 
In the absence of a positive response to levodopa, the drug should discontinue no sooner than 3 months after the onset of therapy [6].

To differentiate between DRD and other conditions alleviated by levodopa, pterins are measured in the cerebrospinal fluid of the patient (CSF). The positive levodopa trial and elevated CSF pterins are strongly suggestive of DRD [7]. The diagnosis can be confirmed by means of molecular genetic testing for mutations in the $\mathrm{GCH} 1$ gene [8].

\section{Clinical case}

A female patient underwent a series of medical examinations and received treatment for DRD at the Neurology Unit of the Central Clinical Hospital № 23 (Yekaterinburg) in 2015-2017. The diagnosis was based on the presence of the heterozygous nucleotide sequence variant c.248g >a (p.Gly83Asp) detected using PCR .

The patient was born in 1982. Her family members first became aware of her symptoms when she was 12 years old. The symptoms included weakness in the legs, gate disturbance, muscle fatigue in the legs exacerbated on walking, a feeling of knee rotation, toe curling while walking, and psychological tension. According to the patient, she also felt occasional weakness in her arms. The patient's parents sought medical advice with a neurologist. Provisional diagnoses included Strümpell-Lorrain disease, paraparesis and paraplegia. The patient was prescribed Baclofen, Neuromultivit, Sirdalud (tizanidine), paraffin wax therapy, massage, and exercise, to no avail. Her condition continued to deteriorate. The patient started feeling very weak, lost control over her legs, discontinued Baclofen and Sirdalud without consulting the neurologist and stopped attending PE classes at school after failing her normative assessment tests (especially, the jumping portion).

Family history. As a child, the patient was raised in a twoparent family and did not have any developmental delays. At the age of 3 years, the patient had chickenpox. After graduating from high school, she went on to earn a degree in economy but was out of work at the time of this study. The patient denied any unhealthy habits. In 2010 she delivered a child by Cesarian section. The patient had no past history of serious infections or allergies. Due to her condition, she was found disabled in 1995 and qualified for category 2 of disability in 2000.

In 2015, she was referred for botulinum toxin therapy, but never received it for reasons unknown. At about that time, her symptoms started to aggravate: she experienced pronounced difficulty walking and could no longer take care of herself.

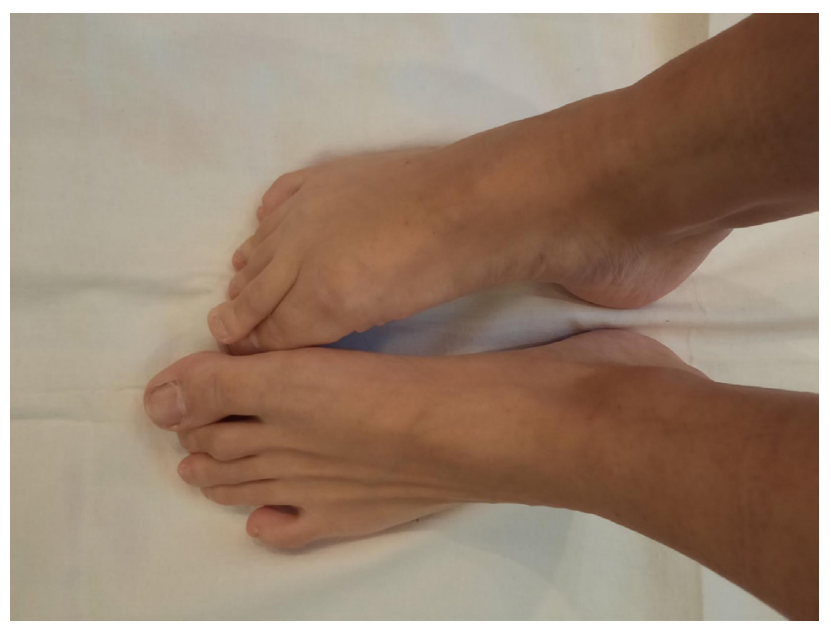

Fig. 1. Dystonia of the right foot before therapy with levodopa
Eventually, she was admitted to the Neurology Unit for further tests.

On admission, her condition was moderately severe, the skin appeared pale and dry. The pulse was regular, 72 beats per min; BP was 130/75, and respiration rate was 16 breaths per min. On a neurological examination, the patient was fully conscious and oriented; speech was scaning. Her cranial nerves were unremarkable. Muscle strength was reduced in the distal legs (the patient scored 3.5 points); muscle tone was increased on the right side (extrapyramidal signs) (Fig. 1); tonic spasms were observed in the lower limbs. Upper limb reflexes were moderate and symmetric; in the lower limbs, reflexes were diminished. No pathologic reflexes were observed. In coordination tests the patient was uncertain; a positive Romberg was present. The patient showed no signs of meningeal irritation. The range of motion was limited in all spinal cord segments. The preliminary diagnosis based on the patient's complaints, medical history and clinical presentations was consistent with encephalopolyradiculoneuropathy, paraparesis, feet dystonia (more pronounced on the right side) and walking impairment. Results of laboratory tests, including complete blood count, urinalysis and blood biochemistry test, were within the normal reference range. On ECG, the sinus rhythm was 73 beats per minute. Electromyoneurography of the lower and upper limbs revealed mild radiculopathy of L4-L5, S1, C7-C8, and Th1, moderate ulnar neuropathy at the elbow and mild axonal neuropathy of the right tibial and peroneal nerves. MRI of the brain revealed grade 1 cortical atrophy. Nothing was suggestive of a focal or diffuse cerebral pathology (Fig. 2) An earlier cervical spine MRI scan performed in 2007 had been suggestive of stage 1 degenerative disc disease at C3-C6 and a small disc osteophyte complex at C5-C6, with no pathologic foci in the spinal cord (Fig. 3). DNA testing for GCHI mutations was conducted on March 13, 2017: the coding sequence and the adjacent introns of the GCHI gene responsible for torsion dystonia (DYT5) were analyzed using Sanger sequencing. The heterozygous variant c. $248 \mathrm{~g}>\mathrm{a}$ ( $\mathrm{p}$.Gly83Asp) was detected. Thus, torsion dystonia was confirmed by molecular genetic testing.

Based on the data from a follow-up MRI scan, the diagnosis was revised and corrected to G24.8 Dopa-responsive dystonia involving both feet, walking impairment; polyradiculoneuropathy in the presence of degenerative disc disease of the cervical and lumbosacral spine; pain syndrome; motor impairment.

The patient was prescribed regular daily exercise, a dopamine mimetic drug, a vasodilator, a hepatoprotective agent, vitamins, and a cholinesterase inhibitor. She was followed up by her local healthcare provider. The patient started

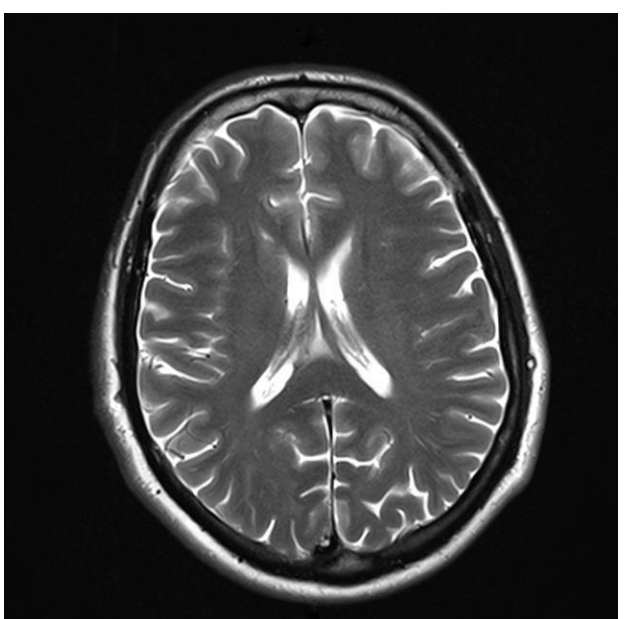

Fig. 2. Brain MRI: grade I cortical atrophy, no signs of focal or diffuse cerebral pathology 
taking the dopamine mimetic drug after the definitive diagnosis was made and continued through pregnancy. When she got pregnant, she reduced the dosage by $50 \%$, with no loss of effect.

\section{Discussion}

Patients with DRD can have 4 different mutations in the gene involved in the synthesis of guanosine triphosphate cyclohydrolase-I $(\mathrm{GCH} 1)$ [9]. This enzyme participates in the synthesis of tetrahydrobiopterin $(\mathrm{BH} 4)$, the tyrosine hydroxylase (TG) cofactor that converts L-tyrosine into L-DOPA, which leads to a reduction in dopamine concentrations in the striatum. Patients with the autosomal-dominant type of inheritance carry this mutant gene on chromosome 14 (14qll-q24.3). Patients with autosomal-recessive inheritance carry this gene on chromosome 11p15.5 of the TG gene [10].

The prevalence of the neurometabolic disease is $0.5-1$ cases per 1 million population [11]; it is probably underreported because some patients present with very mild symptoms. Manifestation of symptoms at the age of 4-8 years is accompanied by parkinsonian features and muscle dystonia resulting in gait disturbance. Because of increased muscle tone in the legs and signs of damage to the pyramidal tracts, the condition can be mistakenly interpreted as cerebral palsy or inherited spastic paraplegia [12]. Over time, dystonia of the lower limbs progresses to generalized dystonia. The disease is characterized by diurnal fluctuations of motor symptoms, which improve in the morning after sleep and aggravate towards evening. Evaluation of the therapeutic effect of levodopa is a good diagnostic technique in patients whose dystonia is not associated with hypoxic-ischemic encephalopathy [13].

In the described clinical case, the patient had reduced muscle strength in the distal leg (3.5 points), increased muscle tone on the right side (extrapyramidal signs) gait disturbance with dystonic movements of the lower libs, diminished reflexes in the lower limbs and a positive Romberg.

Given that the patient's symptoms regressed after the combination therapy with levodopa and carbidopa, the definitive diagnosis was DRD. At present, the patient is free of dystonia symptoms.

\section{References}

1. Segawa M, Ohmi K, Itoh S, Aoyama M, Hayakawa H. Childhood basal ganglia disease with remarkable response to L-Dopa, hereditary basal ganglia disease with marked diurnal fluctuation. Shinryo. 1971; 24: 667-72.

2. Roubertie A, Mariani LL, Fernandez-Alvarez E, Doummar D, Roze E. Treatment for dystonia in childhood. Eur J Neurol. 2012; 19 (10): 1292-9. DOI: 10.1111/j.1468-1331.2011.03649.x.

3. Lin J, Lumsden DE, Gimeno H, et al. The impact and prognosis for dystonia in childhood including dystonic cerebral palsy: a clinical and demographic tertiary cohort study. J Neurol Neurosurg Psychiat. 2014; 85: 1239-44.

4. Gouider-Khouja N, Kraoua I, Benrhouma H, Fraj N, Rouissi A. Movement disorders in neuro-metabolic diseases. Eur J Paediatr Neurol. 2010; 14 (4): 304-7. DOI: 10.1016/i.ejpn.2009.11.005.

5. Wassenberg T, Schouten Ml, Helmich RC, Willemsen MAAP, Kamsteeg EJ, van de Warrenburg BPC. Autosomal dominant $\mathrm{GCH} 1$ mutations causing spastic paraplegia at disease onset [published online ahead of print, 2020 Apr 1]. Parkinsonism Relat Disord. 2020; 74: 12-15. DOI: 10.1016/j.parkreldis.2020.03.019.

6. Wijemanne S, Jankovic J. Dopa-responsive dystonia - clinical and genetic heterogeneity. Nat Rev Neurol. 2015 Jul; 11 (7): 414-

\section{CONCLUSION}

Dopa-responsive dystonia is a rare genetic pediatric-onset disease. Due to diagnostic difficulties, the definitive diagnosis can be delayed. In the early stages of the disease, gait disturbance may be overlooked by the parents. An accurate medical history and a thorough neurological examination focused on detecting the presence of diurnal fluctuations and evaluating the patient's response to medication therapy are instrumental in establishing the accurate diagnosis. The clinical case described in this article might remind healthcare practitioners to stay vigilant about this pathology when examining a patient.

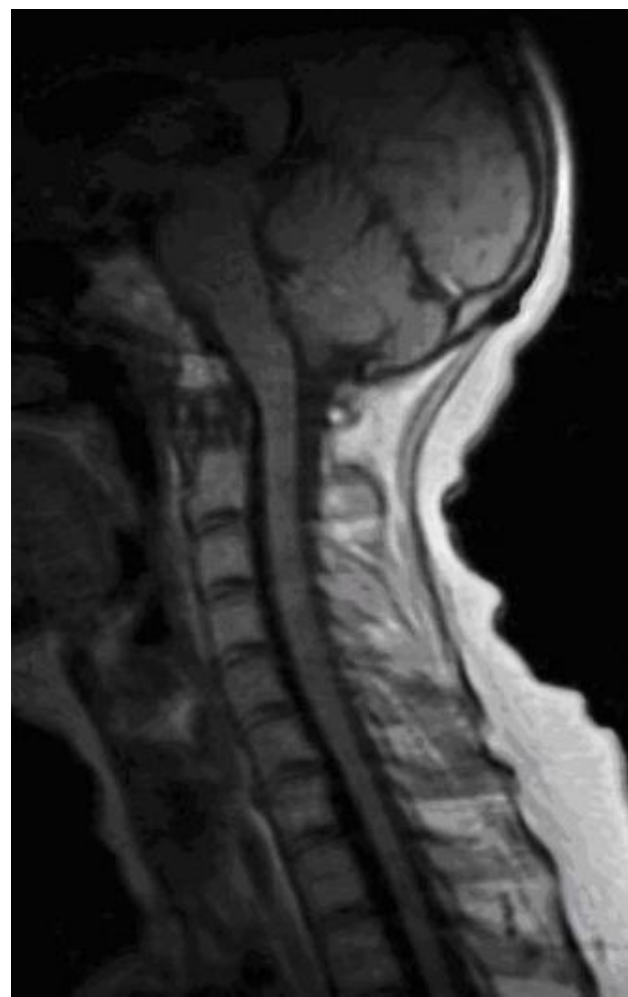

Fig. 3. Cervical spine MRI: stage 1 degenerative disc disease at C3-C6, small disc osteophyte complex at C5-C6. No pathological foci detected

24. DOI: $10.1038 /$ nrneurol.2015.86

7. Nygaard TG, Marsden CD, Duvoisin RC. Dopa-responsive dystonia. Advances in Neurology. 1988; 50: 377-84.

8. Van Hove JL, Steyaert J, Matthijs G, Legius E, Theys P, Wevers R, et al. Expanded motor and psychiatric phenotype in autosomal dominant Segawa syndrome due to GTP cyclohydrolase deficiency. J Neurol Neurosurg Psychiat. 2006; 77: 18-23. Available from: https://DOl.org/10.1136/jnnp.2004.051664.

9. Camargo CHF, Camargos ST, Cardoso FEC, Teive HAG. The genetics of the dystonias - a review based on the new classification of the dystonias. Arquivos de neuropsiquiatria. 2015; 73 (4): 350-8.

10. Lohmann K, Klein C. Update on the genetics of dystonia. Current neurology and neuroscience reports. 2017; 17 (3): 26.

11. Zirn B, Steinberger D, Troidl C, Brockmann K, von der Hagen M, Feiner $\mathrm{C}$, et al. Frequency of $\mathrm{GCH} 1$ deletions in Dopa-responsive dystonia. J Neurol Neurosurg Psychiat. 2008; 79: 183-6. Available from: https://DOl.org/10.1136/jnnp.2007.128413.

12. Lee W-W, Jeon BS. Clinical spectrum of dopa-responsive dystonia and related disorders. Curr Neurol Neurosci Rep. 2014; 14 (7): 461. Available from: https://DOI.org/10.1007/s11910-014-0461-9.

13. Van Egmond ME, Kuiper A, Eggink H, Sinke RJ, Brouwer OF, 
VerschuurenBemelmans CC, et al. Dystonia in children and adolescents: a systematic review and a new diagnostic algorithm.
J Neurol Neurosurg Psychiat. 2015; 86 (7): 774-81. Available from: https://DOI.org/10.1136/jnnp-2014-309106.

\section{Литература}

1. Segawa M, Ohmi K, Itoh S, Aoyama M, Hayakawa H. Childhood basal ganglia disease with remarkable response to L-Dopa, hereditary basal ganglia disease with marked diurnal fluctuation. Shinryo. 1971; 24: 667-72.

2. Roubertie A, Mariani LL, Fernandez-Alvarez E, Doummar D, Roze E. Treatment for dystonia in childhood. Eur J Neurol. 2012; 19 (10): 1292-9. DOI: 10.1111/j.1468-1331.2011.03649.x.

3. Lin J, Lumsden DE, Gimeno H, et al. The impact and prognosis for dystonia in childhood including dystonic cerebral palsy: a clinical and demographic tertiary cohort study. J Neurol Neurosurg Psychiat. 2014; 85: 1239-44.

4. Gouider-Khouja N, Kraoua I, Benrhouma H, Fraj N, Rouissi A. Movement disorders in neuro-metabolic diseases. Eur J Paediatr Neurol. 2010; 14 (4): 304-7. DOI: 10.1016/j.ejpn.2009.11.005.

5. Wassenberg $\mathrm{T}$, Schouten Ml, Helmich RC, Willemsen MAAP, Kamsteeg EJ, van de Warrenburg BPC. Autosomal dominant $\mathrm{GCH} 1$ mutations causing spastic paraplegia at disease onset [published online ahead of print, 2020 Apr 1]. Parkinsonism Relat Disord. 2020; 74: 12-15. DOI: 10.1016/j.parkreldis.2020.03.019.

6. Wijemanne S, Jankovic J. Dopa-responsive dystonia - clinical and genetic heterogeneity. Nat Rev Neurol. 2015 Jul; 11 (7): 41424. DOI: $10.1038 /$ nrneurol.2015.86

7. Nygaard TG, Marsden CD, Duvoisin RC. Dopa-responsive dystonia. Advances in Neurology, 1988: 50: 377-84

8. Van Hove JL, Steyaert J, Matthijs G, Legius E, Theys P, Wevers R, et al. Expanded motor and psychiatric phenotype in autosomal dominant Segawa syndrome due to GTP cyclohydrolase deficiency. J Neurol Neurosurg Psychiat. 2006; 77: 18-23. Available from: https://DOl.org/10.1136/jnnp.2004.051664.

9. Camargo CHF, Camargos ST, Cardoso FEC, Teive HAG. The genetics of the dystonias - a review based on the new classification of the dystonias. Arquivos de neuropsiquiatria. 2015; 73 (4): 350-8.

10. Lohmann K, Klein C. Update on the genetics of dystonia. Current neurology and neuroscience reports. 2017; 17 (3): 26.

11. Zirn B, Steinberger D, Troidl C, Brockmann K, von der Hagen M, Feiner $\mathrm{C}$, et al. Frequency of $\mathrm{GCH} 1$ deletions in Dopa-responsive dystonia. J Neurol Neurosurg Psychiat. 2008; 79: 183-6. Available from: https://DOI.org/10.1136/jnnp.2007.128413.

12. Lee W-W, Jeon BS. Clinical spectrum of dopa-responsive dystonia and related disorders. Curr Neurol Neurosci Rep. 2014; 14 (7): 461. Available from: https://DOl.org/10.1007/s11910-014-0461-9.

13. Van Egmond ME, Kuiper A, Eggink H, Sinke RJ, Brouwer OF, VerschuurenBemelmans CC, et al. Dystonia in children and adolescents: a systematic review and a new diagnostic algorithm. J Neurol Neurosurg Psychiat. 2015; 86 (7): 774-81. Available from: https://DOl.org/10.1136/jnnp-2014-309106. 